\begin{tabular}{lr}
\hline \multicolumn{1}{c}{ D Y N A M I C E C O N O M E T R I C } & M O D E L S \\
DOI: http://dx.doi.org/10.12775/DEM.2016.003 & Vol. 16 (2016) 37-47 \\
\hline $\begin{array}{lr}\text { Submitted November 30, } 2016 & \text { ISSN (online) 2450-7067 } \\
\text { Accepted December 17, 2016 } & \text { ISSN (print) 1234-3862 }\end{array}$
\end{tabular}

Józef Stawicki*

\title{
Using the First Passage Times in Markov Chain Model to Support Financial Decisions on the Stock Exchange
}

\begin{abstract}
A b s t r a c t. The purpose of this article is to present the possibilities of using such a tool as Markov Chain to analyse the dynamics of returns observed at the Warsaw Stock Exchange. Process analysis is the basis for decision-making with regard to the accepted horizon. Expected times for achieving specified states, understood as intervals of rates of return, in particular those describing negative rates of return, are extremely important. In this context, there is a possibility of determining easily the value at risk with the accepted probability.
\end{abstract}

K e y w o r d s: Markov Chain, First passage times, Normal white noise, VaR.

J E L Classification: C58; F47.

\section{Introduction}

Markov Chain can be found a useful tool when describing the phenomenon of changes in the financial market (stock listings, currency exchange rates, trading volume, etc.). This description may serve to identify the mere phenomenon, its character, or to perform comparative analysis of markets. Constructing Markov Chain model begins with a precise determination of states. In the case of analysis of the return rates process, the classes may be intervals in which the rate of return can be contained. Determination of these intervals is defined by the need of research or the consequences of decisions made based on the process that has been identified and described with

\footnotetext{
* Correspondence to: Józef Stawicki, Nicolaus Copernicus University, Faculty of Economic Sciences and Management, 13A Gagarina Street, 87-100 Toruń, Poland, e-mail: stawicki@umk.pl.

(C) 2016 Nicolaus Copernicus University. All rights reserved. http://www.dem.umk.pl/dem
} 
a relevant model. Another very important stage in the construction of Markov Chain model is the choice of an estimation method. Observation of long time series allows applying a method based on microdata, i.e., direct observation of a change of a class. Predictions derived based on the estimated Markov Chain model are of particular significance. Predictions can serve individual or institutional investors, as well as institutions evaluating and supervising a given market. Comparing the behaviours of real stock market processes with classical ones (for instance, with Gaussian white noise) and comparing ergodic distributions is interesting both from a theoretical point of view and practice of decision making processes. This article aims to show how the Markov Chain model through the construction of process states, understood as a range which may contain a particular indicator, can be helpful when describing the phenomenon treated as random and identifying the risk of an investment decision.

The simplicity of the process of finite Markov Chain and its natural interpretation creates opportunities for popularising the proposed analyses.

\section{Markov Chain and Average Passage Times Between States}

\subsection{Homogenous Markov Chain}

The Markov process with a discrete time parameter and discrete phase space is called Markov Chain (Ching, Ng, 2006; Stawicki, 2004). It is determined by a sequence of stochastic matrices of the following form:

$$
\mathbf{P}(\mathrm{t})=\left\lfloor p_{i j}(t)\right\rfloor_{r \times r},
$$

i.e., matrices with positive elements and satisfying additional requirements in the following form:

$$
\forall_{t} \forall_{i} \sum_{j} p_{i j}(t)=1 .
$$

When designating with $\mathbf{D}_{t}$ the unconditional decomposition vector of random variable $Y_{t}$, that is:

$$
\mathbf{D}_{t}=\left[\begin{array}{llll}
d_{1 t}, & d_{2 t}, & \cdots, & d_{r t}
\end{array}\right], \text { where } d_{i t}=\operatorname{Pr}\left\{Y_{t}=i\right\},
$$

we determine the probability with which the process at time $t$ reaches the phase state $i$. The elements of the vector $\mathbf{D}_{t}$ satisfy the conditions below: 


$$
\forall_{t} \forall_{i} \quad d_{i t} \geq 0
$$

and

$$
\forall_{t} \quad \sum_{i} d_{i t}=1 .
$$

The dependence between unconditional decompositions of random variables $Y_{t}$ and $Y_{t-1}$ is shown by the equation resulting from the theorem of total probability:

$$
\mathbf{D}_{t}=\mathbf{D}_{t-1} \cdot \mathbf{P}(t),
$$

thus

$$
\mathbf{D}_{t}=\mathbf{D}_{0} \prod_{k=1}^{t} \mathbf{P}(k) \text {. }
$$

Matrices $\mathbf{P}(\mathrm{t})=\left\lfloor p_{i j}(t)\right\rfloor_{r \times r}$ reflect the mechanism of changes in the distribution of the analysed random variable $Y_{t}$ over time.

The Markov Chain $\left\{Y_{t}, t \in N\right\}$ with the phase space $S=\{1,2, \ldots, r\}$ is referred to as a homogeneous Markov Chain, if conditional probabilities $p_{i j}(t)$ of transition from phase state $i$ to state $j$ in a time unit, which means in the period from $(t-1)$ to $t$, are not dependent on the choice of time $t$, i.e.,

$$
\forall_{t} p_{i j}(t)=p_{i j}
$$

In the case of a homogeneous Markov Chain dependence (5) and (6) take the following form:

$$
\mathbf{D}_{t}=\mathbf{D}_{t-1} \cdot \mathbf{P},
$$

thus

$$
\mathbf{D}_{t}=\mathbf{D}_{0} \cdot \mathbf{P}^{t} \text {. }
$$

For homogeneous Markov Chains described by means of transition matrix $\mathbf{P}=\left\lfloor p_{i j}\right\rfloor$, the expected first passage and return times can be designated. The matrix of these times is determined by the formula (Decewicz, 2011):

$$
M=\left(I-Z+1_{r \times r} Z_{d g}\right) E_{d g}^{-1},
$$

where $Z$ is a fundamental matrix and $E$ is an ergodic matrix. The elements of matrix $M=\left[m_{i j}\right]$ can be interpreted simply as the expected number of steps 
needed to achieve state $j$ after abandoning state $i$. If $i=j$ then we obtain the expected time of the first return.

\subsection{Parameter Estimation of the Transition Matrix Mased on Microdata}

Due to the nature of the studied phenomenon, microdata is understood as the observations of the object in subsequent units and registration of the state of the object in a specific unit. Observation of the state change in the period from $t-1$ to $t$ allows applying a maximum likelihood estimator in the following form:

$$
\hat{p}_{i j}=\frac{\sum_{t=2}^{T} n_{i j}(t)}{\sum_{t=2}^{T} n_{i}(t-1)},
$$

where:

$n_{i j}(t)= \begin{cases}1 & \text { when theobject at time } t-1 \text { was in state } i \text { and at time } t \text { was in state } j \\ 0 & \text { in the adverse sitation }\end{cases}$ $n_{i}(t)= \begin{cases}1 & \text { when the object was at timet was in state } i \\ 0 & \text { in the adverse situation }\end{cases}$

This estimator has the desirable properties of fitting, asymptotic unbiasedness and has an asymptotic normal distribution with the expected value:

$$
E\left(\hat{p}_{i j}\right)=p_{i j},
$$

and the variance:

$$
\operatorname{var}\left(\hat{p}_{i j}\right)=\frac{p_{i j}\left(1-p_{i j}\right)}{\sum_{i=2}^{T} n_{i}(t-1)} .
$$

\section{The Return Rate Process - Comparison with Gaussian White Noise}

Research on the rate of return as a stochastic process has been the subject of a vast number of publications. The fundamental question about the nature of this process mostly concerned the issue of the properties of Gaussian white noise. In the case of the generated process of the rate of return, it is 
easy to obtain the property of normality for both the unconditional distribution and conditional distributions. The transition matrix for a Markov Chain being the model in this process takes the form:

$$
P=\left[\begin{array}{llllll}
0.0228 & 0.1359 & 0.3413 & 0.3413 & 0.1359 & 0.0228 \\
0.0228 & 0.1359 & 0.3413 & 0.3413 & 0.1359 & 0.0228 \\
0.0228 & 0.1359 & 0.3413 & 0.3413 & 0.1359 & 0.0228 \\
0.0228 & 0.1359 & 0.3413 & 0.3413 & 0.1359 & 0.0228 \\
0.0228 & 0.1359 & 0.3413 & 0.3413 & 0.1359 & 0.0228 \\
0.0228 & 0.1359 & 0.3413 & 0.3413 & 0.1359 & 0.0228
\end{array}\right],
$$

where the states of this chain are defined by intervals $\sigma$. The rate of return may belong to one of the following states:

$$
\begin{aligned}
& S_{1}=(-\infty,-2 \sigma), \\
& S_{2}=[-2 \sigma,-\sigma), \\
& S_{3}=[-\sigma, 0), \\
& S_{4}=[0, \sigma), \\
& S_{5}=[\sigma, 2 \sigma), \\
& S_{6}=[2 \sigma, \infty) .
\end{aligned}
$$

This matrix is composed of ergodic vectors which are characterized by Gaussian distribution. Adoption of the intervals in accordance with the threesigma rule facilitates the comparison of the selected processes. This method of determining the states of the observed stock market processes will be maintained in further parts of the work.

To provide an empirical example, analysis was performed of returns of the WIG index as well as of the rate of return for the BUDIMEX company listed on the Warsaw Stock Exchange for the period from 02 February 2003 to 11 August 2016. It provided a series of daily observations amounting to 3475. Despite the many advantages of logarithmic returns, simple returns were analysed due to their clear interpretation.

For the WIG index, the expected value and standard deviation in the examined period were as follows:

$$
\begin{aligned}
& \mathrm{E}(X)=0.000424, \\
& \operatorname{STD}(X)=0.0123 .
\end{aligned}
$$

The matrix of transition probabilities takes the form: 


$$
P=\left[\begin{array}{llllll}
0.1887 & 0.0849 & 0.2642 & 0.2736 & 0.1321 & 0.0565 \\
0.0637 & 0.1306 & 0.3248 & 0.3408 & 0.1051 & 0.0350 \\
0.0226 & 0.1013 & 0.3515 & 0.4162 & 0.0951 & 0.0133 \\
0.0192 & 0.0833 & 0.4034 & 0.3842 & 0.0885 & 0.0214^{\circ} \\
0.0296 & 0.0533 & 0.3876 & 0.4053 & 0.0976 & 0.0266 \\
0.0132 & 0.0395 & 0.3289 & 0.3553 & 0.2105 & 0.0526
\end{array}\right] .
$$

When comparing this matrix with the transition matrix for Gaussian white noise, hypothesis $H_{0}$ assuming the equality of matrices must be rejected (Decewicz, 2011, p. 51). Test $\chi_{P}^{2}=287.67$ relative to $\chi^{2} 30, \alpha=0,05=53.67$.

The comparison of the ergodic distribution for such a design of the chain with the process of Gaussian white noise is presented in Figure 1.

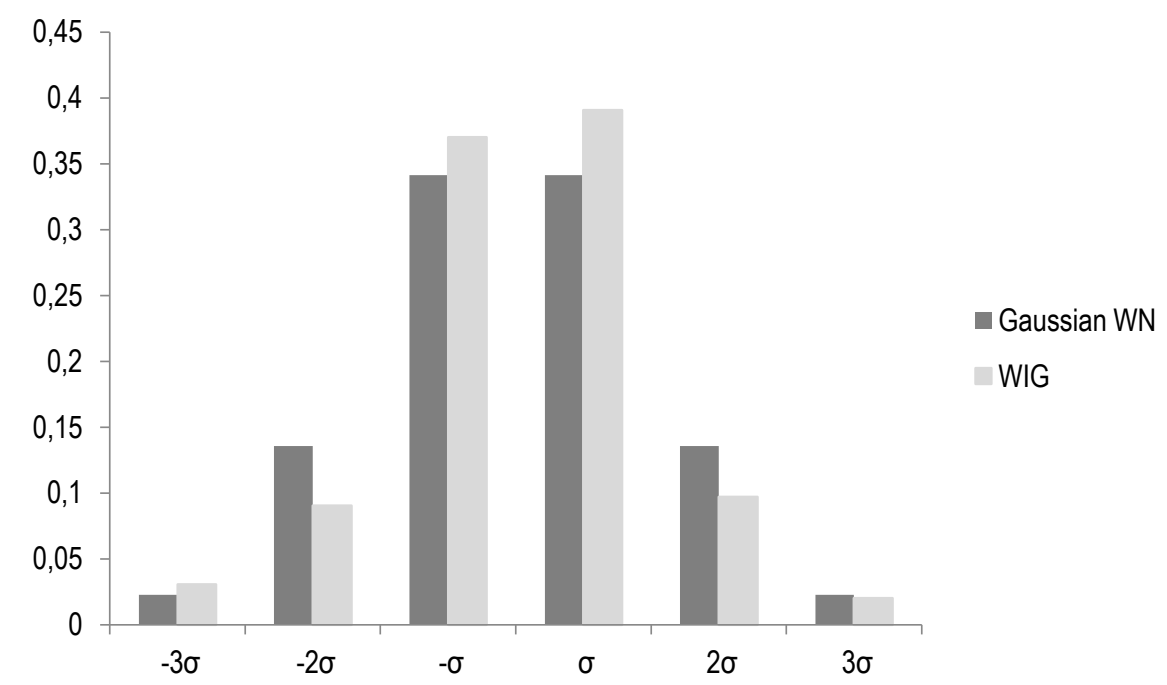

Figure 1. The comparison of white noise with the ergodic distribution of the rate of return obtained from the WIG index

For the rate of return obtained from BUDIMEX, the expected value and standard deviation in the examined period were as follows:

$$
\begin{aligned}
& \mathrm{E}(X)=0.000787, \\
& \operatorname{STD}(X)=0.0224 .
\end{aligned}
$$

The matrix of transition probabilities takes the following form: 


$$
P=\left[\begin{array}{llllll}
0.1519 & 0.1013 & 0.2152 & 0.2911 & 0.1139 & 0.1266 \\
0.0347 & 0.1199 & 0,3817 & 0.2808 & 0.1325 & 0.0505 \\
0.0201 & 0.1011 & 0.4485 & 0.3507 & 0.0622 & 0.0174 \\
0.0128 & 0.0640 & 0.4389 & 0.3672 & 0.0897 & 0.0459 \\
0.0230 & 0.0918 & 0.4295 & 0.2787 & 0.1311 & 0.0459 \\
0.0374 & 0.1589 & 0.3832 & 0.1869 & 0.1495 & 0.0841
\end{array}\right] .
$$

When comparing this matrix with the transition matrix for Gaussian white noise, hypothesis $H_{0}$ assuming the equality of matrices must be rejected (Decewicz, 2011, p. 51). Test $\chi_{P}^{2}=375.87$ relative to $\chi_{30, \alpha=0,05}^{2}=53.67$. Comparing the different rows of the matrix, i.e., comparing the conditional distributions, it must be noted that in the case each of the conditional distribution must be rejected. For $\alpha=0.05$ and the fifth order the table value $\chi^{2}{ }_{5, \alpha=0,05}=11.07$.

The comparison of the ergodic distribution for such a design of the chain with the process of Gaussian white noise is presented in Figure 2.

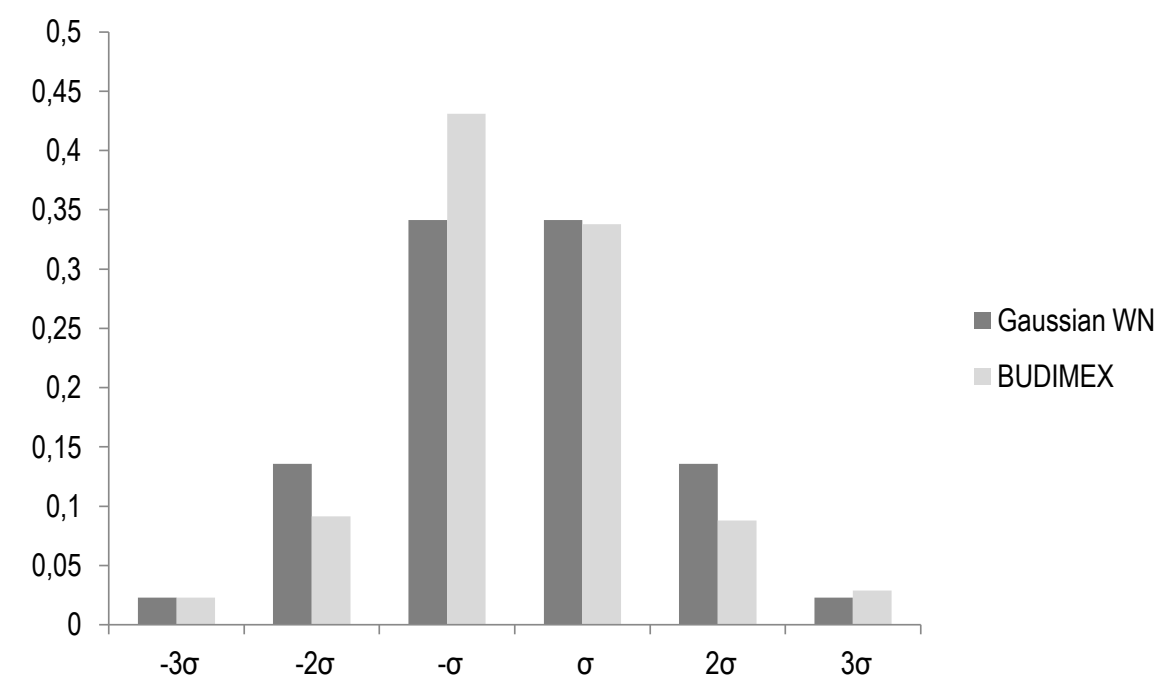

Figure 2. The comparison of Gaussian white noise with the ergodic distribution of the rate of return obtained from the BUDIMEX company index 


\section{First Passage Times}

Analysis of the expected times of transition from state $i$ to state and $j$ is extremely important from the point of view of an individual or institutional investor. The investor is able to determine the horizon for the portfolio being constructed or decide about the position that should be taken.

Calculations were made using the WinQSB package.

The matrix for the WIG index takes the following form:

$$
M=\left[\begin{array}{cccccc}
32.6 & 11.6 & 3.0 & 2.9 & 9.8 & 45.1 \\
37.6 & 11.0 & 2.8 & 2.7 & 10.1 & 46.3 \\
39.2 & 11.4 & 2.7 & 2.5 & 10.3 & 47.5 \\
39.4 & 11.6 & 2.6 & 2.6 & 10.4 & 47.1 \\
39.1 & 11.9 & 2.6 & 2.5 & 10.3 & 46.9 \\
39.7 & 12.2 & 2.7 & 2.6 & 9.1 & 45.7
\end{array}\right] .
$$

It is worth noting that the expected passage times from any state to the state which is characterized by a value greater than twice the standard deviation are very large and in excess of one month. It should be noted, however, that negative returns are faster achieved than non-negative ones. Somewhat different is the situation of the single company tested. The analysed rate of return for BUDIMEX was characterized by the following first passage times matrix:

$$
M=\left[\begin{array}{llllll}
43.9 & 11.1 & 2.9 & 3.3 & 11.4 & 30.5 \\
49.9 & 10.9 & 2.5 & 3.2 & 11.3 & 33.7 \\
50.7 & 11.2 & 2.3 & 3.0 & 12.2 & 34.9 \\
51.1 & 11.6 & 2.3 & 2.9 & 11.9 & 34.7 \\
50.5 & 11.3 & 2.4 & 3.2 & 11.4 & 33.9 \\
49.7 & 10.4 & 2.5 & 3.6 & 11.0 & 32.4
\end{array}\right] .
$$

Here, the expected passage times to the class of rates lower than twice the standard deviation are larger than the expected times of the first passage times to the state with a rate of return higher than twice the standard deviation. 


\section{Determination of VaR using Markov Chain}

Quantification of risk usually occurs by determining the measure known as VaR. There are many ways of determining the value at risk depending on the model which is used by analysts or investors. Literature on this subject is really abundant. This article proposes to use the Markov Chain methodology to determine VaR. When referring to the classic definition of value at risk (Osińska, 2006; Doman, Doman, 2009), one should pay attention to the fact that the market value is linked to the present rate of return and the horizon, i.e., the accepted time interval. These two elements are exposed in a Markov Chain. One takes the form of state as a range of the rate of return, the other is linked to the time aggregation (chains based on daily, weekly, and monthly data) and the expected time of reaching a specified state for the first time.

The idea is to construct states appropriately including the state of risk

$$
S_{1}=(-\infty,-V a R),
$$

as well as the state which contains the rate of return at the present time $T$ $S_{B}=[x, y)$. State $S_{2}$ can be determined in the form $S_{2}=[\operatorname{VaR}, 0)$ as long as the current value of the rate satisfies the condition $x \geq 0$. This structure state of state $S_{2}$ is not necessary and may be determined as $S_{2}=[\operatorname{VaR}, z)$ providing $x \geq z$.

Value at risk is determined empirically by changing the range of state $S_{1}$ and thus at the same time the interval of state $S_{2}$ until the time when the transition probability $p_{B 1}$ in matrix $P$ reaches the assumed level of risk.

Analysis of the transition matrix of the BUDIMEX company allows to determine $\mathrm{VaR}$ in accordance with the above manner. It was assumed that the last observed rate of return was contained in the interval $S_{B}=S_{4}=[0.0 ; 0.01)$. The rate of return as of $8^{\text {th }}$ of November, 2016 was $r=0.004149$.

Other classes were determined in as follows: 


$$
\begin{aligned}
& S_{1}=(-\infty ;-\operatorname{VaR}), \\
& S_{2}=[-\operatorname{VaR} ;-0.01), \\
& S_{3}=[-0.01 ; 0), \\
& S_{4}=[0 ; 0.01), \\
& S_{5}=[0.01 ; 0.03), \\
& S_{6}=[0.03 ; \infty) .
\end{aligned}
$$

The current state, i.e., state $S_{B}$, is state $S_{4}$.

The transition matrix allowing $p_{B 1} \leq 0.05$ is the following matrix:

$$
P=\left[\begin{array}{cccccc}
0.1308 & 0.2290 & 0.1122 & 0.1822 & 0.1729 & 0.1729 \\
0.0687 & 0.1915 & 0.1944 & 0.2456 & 0.2311 & 0.0687 \\
0.0608 & 0,1900 & 0.2219 & 0.3191 & 0.1626 & 0.0456 \\
0.0494 & 0.1751 & 0.2091 & 0.3069 & 0.1957 & 0.0639 \\
0.0417 & 0.2072 & 0.1699 & 0.3010 & 0.1967 & 0.0835 \\
0.0836 & 0.2545 & 0.1418 & 0.1964 & 0.1673 & 0.1564
\end{array}\right],
$$

for which state $S_{1}=(-\infty ;-0.03)$. That means that VAR $=-0.03$.

The matrix determined in that way has also interesting expected times of achieving individual states. This matrix takes the following form:

$$
M=\left[\begin{array}{llllll}
16.2 & 4.8 & 5.9 & 4.1 & 5.3 & 12,3 \\
17.4 & 5.1 & 5.4 & 3.8 & 5.0 & 13.9 \\
17.5 & 5.1 & 5.3 & 3.5 & 5.4 & 14.2 \\
17.8 & 5.2 & 5.3 & 3.6 & 5.2 & 14.0 \\
17.9 & 5.0 & 5.6 & 3.6 & 5.2 & 13.7 \\
17.1 & 4.7 & 5.8 & 4.1 & 5.3 & 12.6
\end{array}\right] .
$$

The expected time of the first attainment of the state of risk from the present state is relatively high and amounts to 17.8 days.

\section{Conclusions}

The proposals do not exhaust all the possibilities offered by the tool in the form of Markov Chain. A comparison of the processes with Gaussian white noise showed a considerable discrepancy. This only confirms the results already described by the subject literature. 
Especially important is the proposal of determining VaR with a very simple interpretation in the Markov Chain model. The result in the form of expected time of achieving the appropriate states is significant. This applies to both processes where states were constructed by standard deviation and to the construction of states in search of value at risk. The above results are an incentive for undertaking further research. In particular, this concerns the influence of aggregation of states in Markov Chain on the results presented in the work.

\section{References}

Osińska, M. (2006), Ekonometria finansowa, Polskie Wydawnictwo Ekonomiczne, Warszawa.

Doman, M., Doman, R. (2009), Modelowanie zmienności i ryzyka,Wolter Kluwer Polska, Kraków.

Decewicz, A. (2011), Probabilistyczne modele badań operacyjnych, Oficyna Wydawnicza SGH, Warszawa.

Podgórska, M., Śliwka, P., Topolewski, M., Wrzosek, M. (2002), Łańcuchy Markowa w teorii $i$ w zastosowaniach, Oficyna Wydawnicza SGH, Warszawa.

Ching, W., Ng, M.,K. (2006) Markov Chains Models, Algorithms and Applications, Springer Science+Business Media.

Stawicki, J. (2004), Wykorzystanie łańcuchów Markowa w analizie rynku kapitałowego, Wydawnictwo UMK, Torun.

\section{Wykorzystanie oczekiwanych czasów pierwszego przejścia i powrotu w modelu łańcuchów Markowa do wspomagania decyzji finansowych na giełdzie}

Z a r y s t r e ś c i. Artykuł prezentuje możliwość wykorzystania narzędzia jakim są łańcuchy Markowa do analizy dynamiki stóp zwrotu obserwowanych na GPW. Analiza procesu jest podstawą podejmowania decyzji w zadanym horyzoncie. Oczekiwane czasy osiągnięcia zadanych stanów, w szczególności opisujących ujemne stopy zwrotu, jest niezwykle ważne. W tym kontekście pojawia się możliwość łatwego wyznaczania wartości narażonej na ryzyko z zadanym prawdopodobieństwem.

S łow a k l u c z o w e: Łańcuchy Markowa, oczekiwane czasy pierwszego przejścia i powrotu, gaussowski biały szum, VaR. 
